Abstracta Iranica Abstracta Iranica

Revue bibliographique pour le domaine irano-aryen

Volume 37-38-39 | 2018

Comptes rendus des publications de 2014-2016

\title{
Yasmina Wicks. Bronze 'Bathtub' Coffins in the Context of 8th-6th Century B.C.E. Babylonian, Assyrian and Elamite Funerary Practices
}

Javier Álvarez-Mon

\section{(2) OpenEdition \\ Journals}

Electronic version

URL: http://journals.openedition.org/abstractairanica/44879

DOI: 10.4000/abstractairanica.44879

ISBN: 1961-960X

ISSN: 1961-960X

Publisher:

CNRS (UMR 7528 Mondes iraniens et indiens), Éditions de l'IFRI

\section{Electronic reference}

Javier Álvarez-Mon, "Yasmina Wicks. Bronze 'Bathtub' Coffins in the Context of 8th-6th Century B.C.E.

Babylonian, Assyrian and Elamite Funerary Practices », Abstracta Iranica [Online], Volume 37-38-39 | 2018, document 10, Online since 30 December 2018, connection on 02 October 2020. URL : http://

journals.openedition.org/abstractairanica/44879; DOI : https://doi.org/10.4000/abstractairanica. 44879

This text was automatically generated on 2 October 2020.

Tous droits réservés 


\section{Yasmina Wicks. Bronze 'Bathtub' Coffins in the Context of 8th-6th Century B.C.E. Babylonian, Assyrian and Elamite Funerary Practices}

Javier Álvarez-Mon

\section{REFERENCES}

Yasmina Wicks. Bronze 'Bathtub' Coffins in the Context of 8th-6th Century B.C.E. Babylonian, Assyrian and Elamite Funerary Practices. Oxford: Archaeopress, 2015, 169 p., three appendices, 72 black \& white figures.

1 This monograph offers the first comprehensive study of a corpus of bronze coffins found in Assyrian, Babylonian and Elamite funerary contexts dating from the $8^{\text {th }}$ to the $6^{\text {th }}$ century BC. It is a much-expanded, updated and corrected version of an Honours thesis of the same title submitted to The University of Sydney, Australia, in 2012. The book is divided in six chapters. Chapter 1. Introduces the reader to the corpus, the manufacture of the coffins, workshops, their origins and dating. Each burial is carefully examined, bringing forth the available literature and the archaeological context. Chapter 2. Brings the reader into the domain of funerary remains, using the data provided by excavation reports and various secondary publications. Chapter 3. Takes a step outside the circle of the bronze coffins to offer a review of the textual and archaeological evidence pertaining to funerary beliefs and rituals, and places the bronze coffins within this context. Chapter 4. Discusses the ideological aspects of the bronze "bathtub" coffins stressing their unique shape and material. Chapter 5. Seeks to place the coffins in historical context, discussing their distribution, elite funerary contexts, and the implications of three distinct regions sharing such a unique burial receptacle. Finally, Chapter 6. Brings together the various dimensions of the study to convey a thoughtful appraisal of the possible origins and significance of these unique 
coffins. The book is well documented by 72 figures and includes three appendices: a catalogue of the bronze coffins; an inventory of the Nimrud bronze "bathtub" coffin goods, and texts.

2 This book carves a significant space in the history of first millennium BC funerary practices in the ancient Near East. The author synthesises previous literature and articulates the multiple avenues of research opened to us by this distinctive corpus of objects. The implications of this study are many and affect consideration of the individual characteristics of the coffins' shape and material and its funerary and sociocultural contexts in the latter part of the Neo-Elamite period. Not surprisingly, new light is shed on two related areas of study involving the bronze coffins: the Queen's burials from Nimrud and Persian Achaemenid elite funerary practices. In the first case, a re-examination of the numerous "bathtub"-shaped depressions in the floor of certain rooms in Assyrian palaces strongly suggests that the "coffins" had led previous lives as ritual basins. Furthermore, the reconstruction of the deposition of the coffins at Nimrud persuasively maps out dramatic events preceding the final days of the palace's capture in $612 \mathrm{BC}$; suggesting attempts to move the coffins and related goods into more suitable hiding spots. Finally, this study adds more evidence for continuity between Elam and Persia, in this case for elite funerary practices and ideology. This heritage is critical when considering the nature of the limited available Persian evidence: the presumed "golden" coffin containing the body of Cyrus, two elite bronze coffin burials (probably both of females) from Susa dated to the $5^{\text {th }}$ century BC, and the apparent deposition of (metal?) coffins in the royal rock-cuts tombs from Naqsh-e Rustam (Yasmina Wicks, Javier Álvarez-Mon, François Bridey and Julien Cuny, Iranica Antiqua 2018 forthcoming).

\section{AUTHORS}

\section{JAVIER ÁLVAREZ-MON}

Department of Ancient History, Macquarie University, Australia 